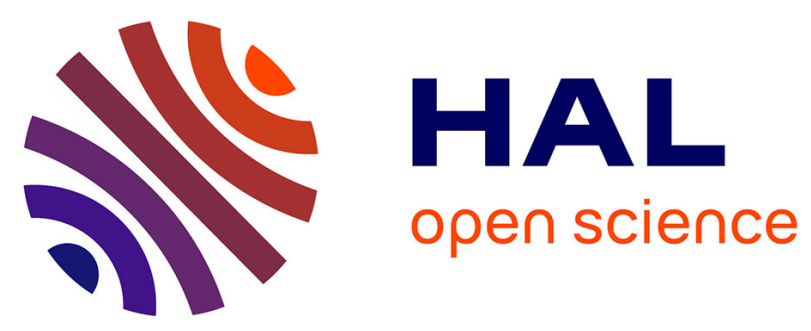

\title{
Thermal analysis and archaeological chronology: The ancient mortars of the site of Baradello (Como, Italy)
}

Laura Rampazzi, Cristina Corti, Roberto Bugini, Antonio Sansonetti, Marco Biraghi, Lanfredo Castelletti, Isabella Nobile, Clelia Orsenigo

\section{- To cite this version:}

Laura Rampazzi, Cristina Corti, Roberto Bugini, Antonio Sansonetti, Marco Biraghi, et al.. Thermal analysis and archaeological chronology: The ancient mortars of the site of Baradello (Como, Italy). Thermochimica Acta, 2013, 572, pp.71-84. 10.1016/j.tca.2013.08.015 . hal-01701942

\section{HAL Id: hal-01701942 \\ https://hal.science/hal-01701942}

Submitted on 6 Feb 2018

HAL is a multi-disciplinary open access archive for the deposit and dissemination of scientific research documents, whether they are published or not. The documents may come from teaching and research institutions in France or abroad, or from public or private research centers.
L'archive ouverte pluridisciplinaire HAL, est destinée au dépôt et à la diffusion de documents scientifiques de niveau recherche, publiés ou non, émanant des établissements d'enseignement et de recherche français ou étrangers, des laboratoires publics ou privés. 


\title{
Thermal analysis and archaeological chronology: the ancient mortars of the site of Baradello (Como, Italy)
}

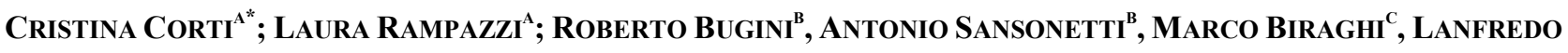 \\ CASTElletti $^{\mathrm{c}}$, ISABella NOBILE ${ }^{\mathrm{c}}$, Clelia ORSEnigo $^{\mathrm{c}}$
}

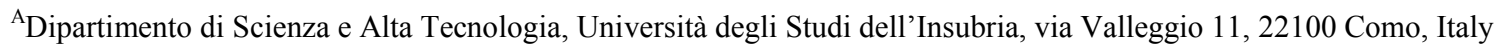 \\ ${ }^{\mathrm{B}}$ Istituto per la Conservazione e la Valorizzazione dei Beni Culturali, Unità di Milano 'Gino Bozza', Area della Ricerca Milano 3 \\ Bicocca, via Cozzi 53, 20125 Milano, Italy \\ 'Museo Archeologico 'Paolo Giovio', Piazza Medaglie d'Oro 1, 22100 Como, Italy
}

*Corresponding author

Cristina Corti, email address: cristina.corti@uninsubria.it

\begin{abstract}
Mortar is an artificial material, commonly used since ancient times and widely conserved, in many cases in good conditions, to the present day. In this study, mortars from different structures of the medieval site of Baradello (Como, Italy) were analyzed, in order to characterize the materials and to help archaeologists to define a building chronology, only partially hypothesized, so far. Firstly, thin sections were prepared and observed by optical microscopy, then samples were analyzed by TG-DSC, XRD, FTIR and SEM-EDX. TG-DSC proved to be the most useful technique for the purpose, because the treatment of its data pointed out differences between the architectural structures, suggesting a possible building chronology of the site.
\end{abstract}

Keywords: TG-DSC, medieval mortar, chronology, Baradello, binder/aggregate ratio, hydraulicity index

\section{INTRODUCTION}

Mortar is an artificial material, commonly used since ancient times and widely conserved, in many cases in good conditions, to the present day. The ease of preparation, the effortless availability of raw materials, the features of durability and versatility, have contributed to the spreading of mortar, both as a joint element of bricks or stones, and as a coating (plaster). All these factors have diffused the use of mortar in civil and military structures. The first rationalization of knowledge on mortars, containing 'recipes' and technical information, dates back to the 'De Architectura' by Vitruvius (I century BC); other evidences are reported in the 'Naturalis Historia' of Pliny (I century $\mathrm{AD}$ ) and 'De Agri Cultura' of Cato (II century BC). The information gathered in these works have been used for centuries by the experts: the manufacturers of the Renaissance, but still even those of the XIX century, admired the perfection and endurance especially of ancient Roman mortars and tried to copy techniques and materials. The historical sources contain valuable information on the techniques of production and implementation of the mortars, obviously in a general view. The use of chemical and mineralogical analysis techniques, instead, allows collecting information on 
specific cases, in terms of technology and raw materials. Despite their widespread use in ancient buildings, in fact, it is generally difficult to obtain historical information on the origin of the raw materials or on the production technologies, because mortars are generally considered as 'poor and common' materials: this is a challenge for their characterization. Due to their largely variable nature, depending on the period and place of preparation, mortars are traces of the progress in building technology and economical status of a population; this information can be obtained on the basis of the refinement of techniques and materials used. Even in their 'simple' function, mortars are a very complex material, consisting of at least two phases, a binder and an aggregate, with possible additives. This complexity can be the clue to understand their production technology, to characterise a broad spectrum of raw materials and to identify stratigraphies: all these aspects can be used to define different constructive histories, observing possible variations in mixtures, in additives, in provenance of the stones used to prepare them [1-8]. Finally, information about the use (civil, military, etc.) of the structures can be inferred from the characteristics of their mortars, i.e. refinement, care in the choice of materials, etc. The analyses of mortars are also important in something which is possible to call 'reverse engineering' process, in order to find the best compatible materials when restoring the original ones.

Ancient mortars are composite materials, generally mixtures of lime (as a binder), sand (as an aggregate) and water, sometimes with organic or inorganic additives. The binder and the water give workability to the material, while the aggregate adds volume and influences its mechanical properties. Mud was probably the first binder used, then replaced, since VI millennium BC, by gypsum and then by lime; the latter became the basic component of most of ancient mortars [3].

Due to this complex composition, different analytical techniques are generally required to characterize mortars: the most relevant are Fourier transform infrared spectroscopy (FTIR) [9-11], X-ray diffraction (XRD) [1, 2, 4, 9, 10, 12 19], thermal analysis (TG, DTG, DTA, DSC) [2, 9-17, 19-21] sometimes coupled with FTIR [20], electron microscopy with microprobe for elemental analysis (SEM-EDX) [1-3, 10, 12, 13, 17], Raman spectroscopy [12], optical microscopy on thin sections $[1,3,13,14,17]$, inductively coupled plasma atomic emission spectrometry (ICP-AES) $[4,14,15,20]$, ionic chromatography $[14,15]$, x-ray fluorescence (XRF) [1, 10], flame emission atomic spectroscopy [15], mercury intrusion porosimetry [10], neutron activation analysis (NAA) [18]. Many critical issues are connected with the analysis of mortars. For example, given their particular composition and, often, inhomogeneity, it could be difficult to prepare aliquots for analysis truly representative of the entire sample, or to obtain reproducible results. The complex visual identification of the phases binder and aggregate, often impossible to distinguish without observation in thin sections (not always available in a short time), must also be added. Every mortar constitutes a specific case of analysis, according to its age, location, technology, background and, therefore, features.

This study deals with the mortars of the archaeological site surrounding the Baradello Castle (Como, Italy). The input was given by the team of archaeologists that, during a recent excavation, has brought to light several masonry structures. Their history was only partially defined by means of the visual analysis of buildings and the examination of historical resources that attest their construction. Therefore, the purpose of this study is to trace a constructive history by means of chemical and mineralogical analysis of the mortars used. Sampling was conducted on all accessible masonry structures and has been designed to obtain the maximum representativeness. The mineralogical analysis of thin sections was followed by X-ray diffraction (XRD), Fourier transform infrared spectroscopy (FTIR), thermal analysis (TG-DSC) (which proved to be particularly informative) and, finally, observation with a scanning electron microscope equipped with X-ray microprobe for the elemental analysis (SEM-EDX). 


\section{MATERIALS AND METHODS}

\subsection{Archaeological background}

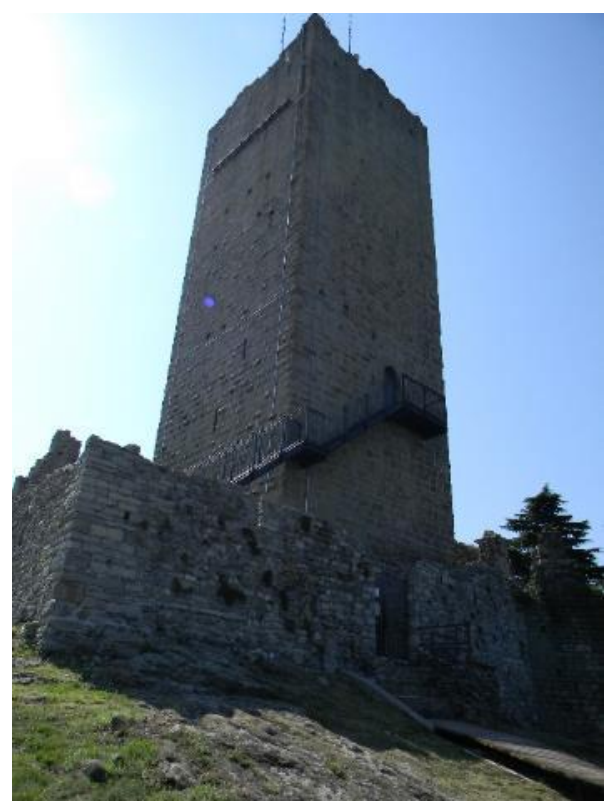

Figure 1 - The Tower of the Baradello Castle, Como, Italy

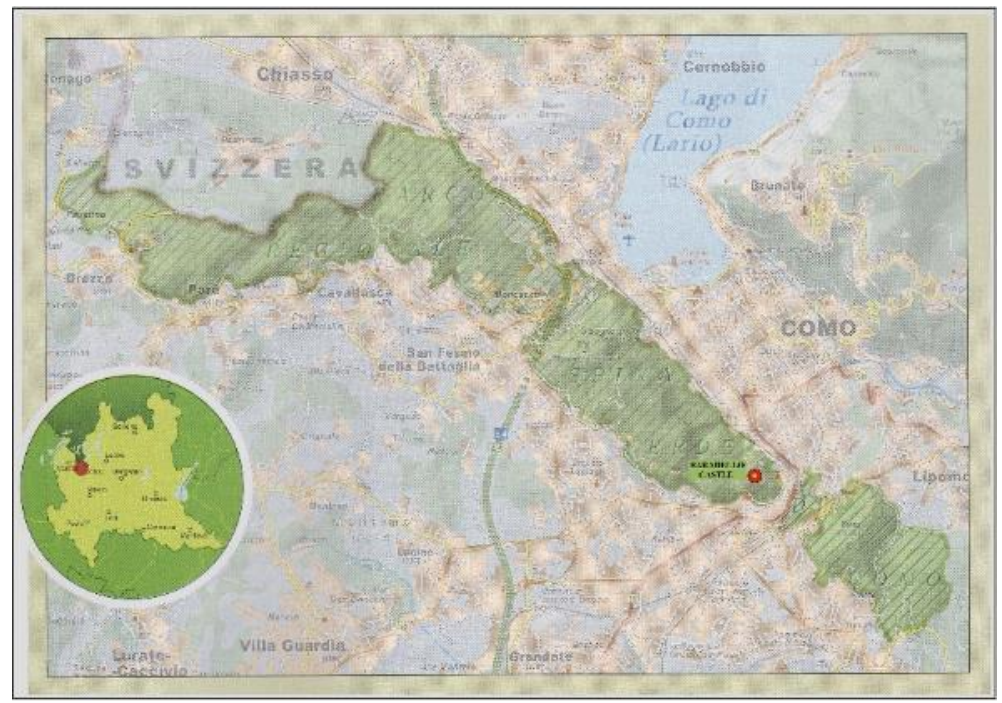

Figure 2 - Map of Como, Italy, indicating the position of the Baradello Castle

Baradello Castle (Figure 1) was built in a dominant position (432 $\mathrm{m}$ above mean sea level) as it was meant to be an important observation point within the defense system around the city of Como (Figure 2).

The fortification includes many structures, such as two concentric walls around the tower, and it was erected in three different periods: the first framework dates to Early Middle Ages, the second to XII century and the third to Viscontis Age (XIV-XV century).

The two last phases were already examined more than fifty years ago [22], therefore the new survey focused on the earliest stage of the fortification. The new project, which began in 2008, is still in progress [23] and is being carried out with a multidisciplinary approach that involves archival researches, reconnaissance (on land, LiDar application), 
archaeological excavations (Figure 3), stratigraphic studies of walls and lab-analysis of the castle's mortars (chemical, $\left.{ }^{14} \mathrm{C}\right)$.

The study has achieved important results that allowed us to identify a third circle of the walls (Figure 3) which dates back to the beginning of Early Middle Ages.

The outer facades of the walls are made of pebbles of gonfolite (a sedimentary rock of Oligocene and Miocene epoch) arranged in sub-horizontal rows and reemployed material (such as fragments of bricks and carved stones of Roman age) bound by strong mortar, while the emplekton (the rubble stone fill) is composed of plentiful mortar and small stones.

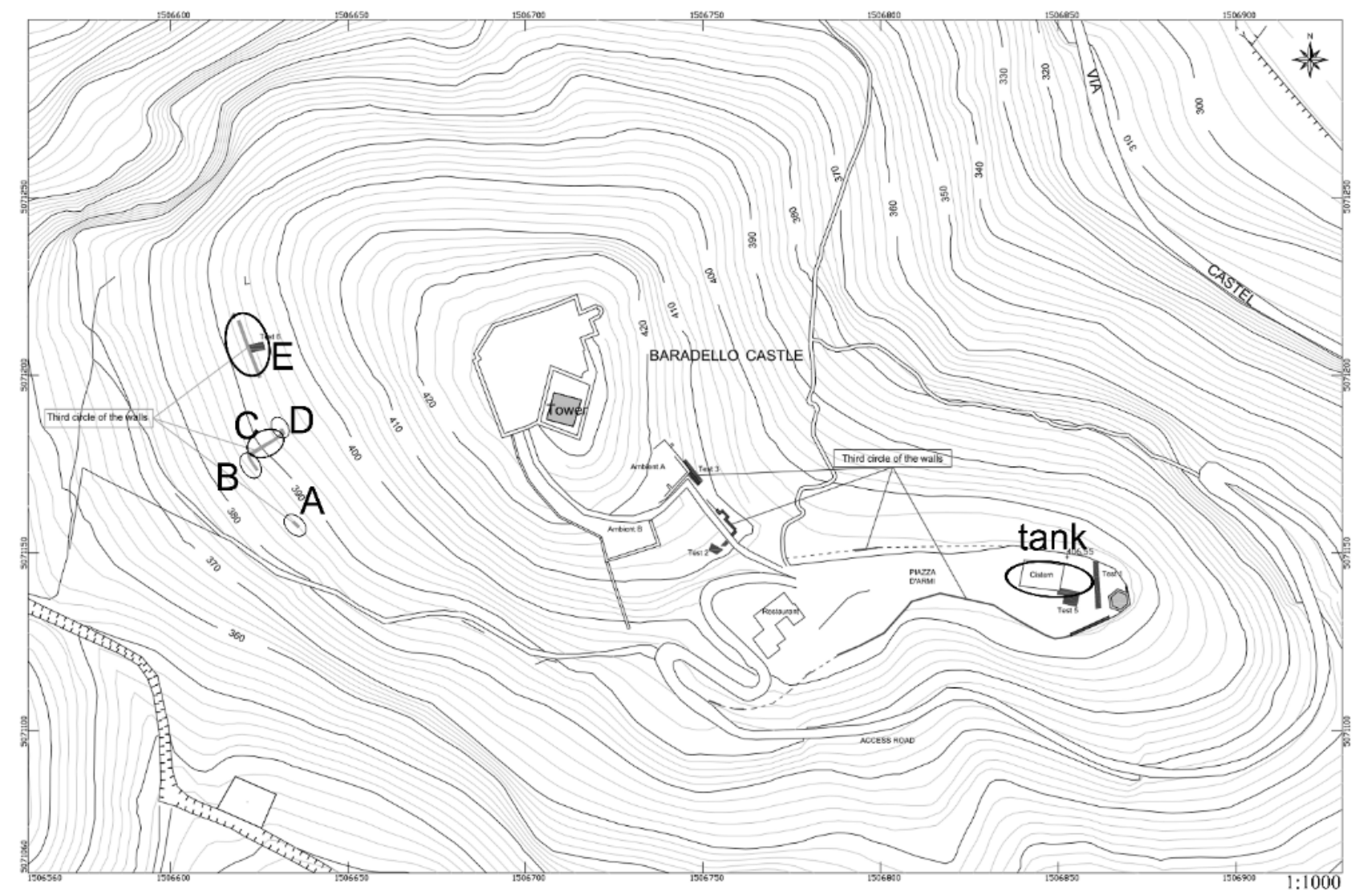

Figure 3 - Site map

\subsection{Sampling}

The samples were taken from the places that, after a macroscopic assessment and an historical classification by the archaeologists, were considered as representative of the different typologies of mortars. Since the purpose of this study was the classification of mortars and not a survey on their state of preservation, only macroscopically non-degraded samples were taken. For every masonry structure, a number of representative samples was taken, choosing, when possible, semidetached fragments and using chisels only when necessary.

Once in the laboratory, the outermost parts of the samples were removed, in order to favour the analysis of the core of the mortars. The samples did not present layers and could be considered as homogeneous.

A site map is shown in Figure 3.

Twenty-five samples were collected, as shown in Figure 4 and described in Table 1, where the structure of provenance and the age of construction, hypothesized by the archaeologists on the basis of historical documents or stylistic observations, are reported. 
Samples coming from the tank showed at naked eye the presence of cocciopesto, which gives them a peculiar pinkishreddish colour (Figure 5). Cocciopesto is composed by crushed terracotta or bricks and was widely used since Roman age in order to induce a hydraulic setting to the material for the coating of tanks, wells, aqueducts, etc., when volcanic materials such as pozzolana were not available [3, 24]. Hence these mortars are considered hydraulic, due to the formation of calcium silicates at the interface between the brick fragments and lime ('pozzolanic reactions'), giving particular characteristics of adhesion, strength, impermeability to water and resistance to continuous contact with damp $[16,25,26]$. As already said, these materials were commonly used in structures such as cisterns, baths, aqueducts, tanks to catch fishes, etc., in permanent or frequent contact with water. The use of crushed bricks in lime mortars is described in Vitruvius (book II, chapter VII, paragraphs XVII-XVIII [27]), which quotes this composite material as opus testaceum.

Representative aliquots were collected from every sample, discarding the surfaces that were exposed to the atmosphere or to the soil. The fragments were then grinded and homogenized in a stainless steel mechanical ball mill Tac $400 \mathrm{MS}$ and kept in clean Kartell LPDE vials until analysis.

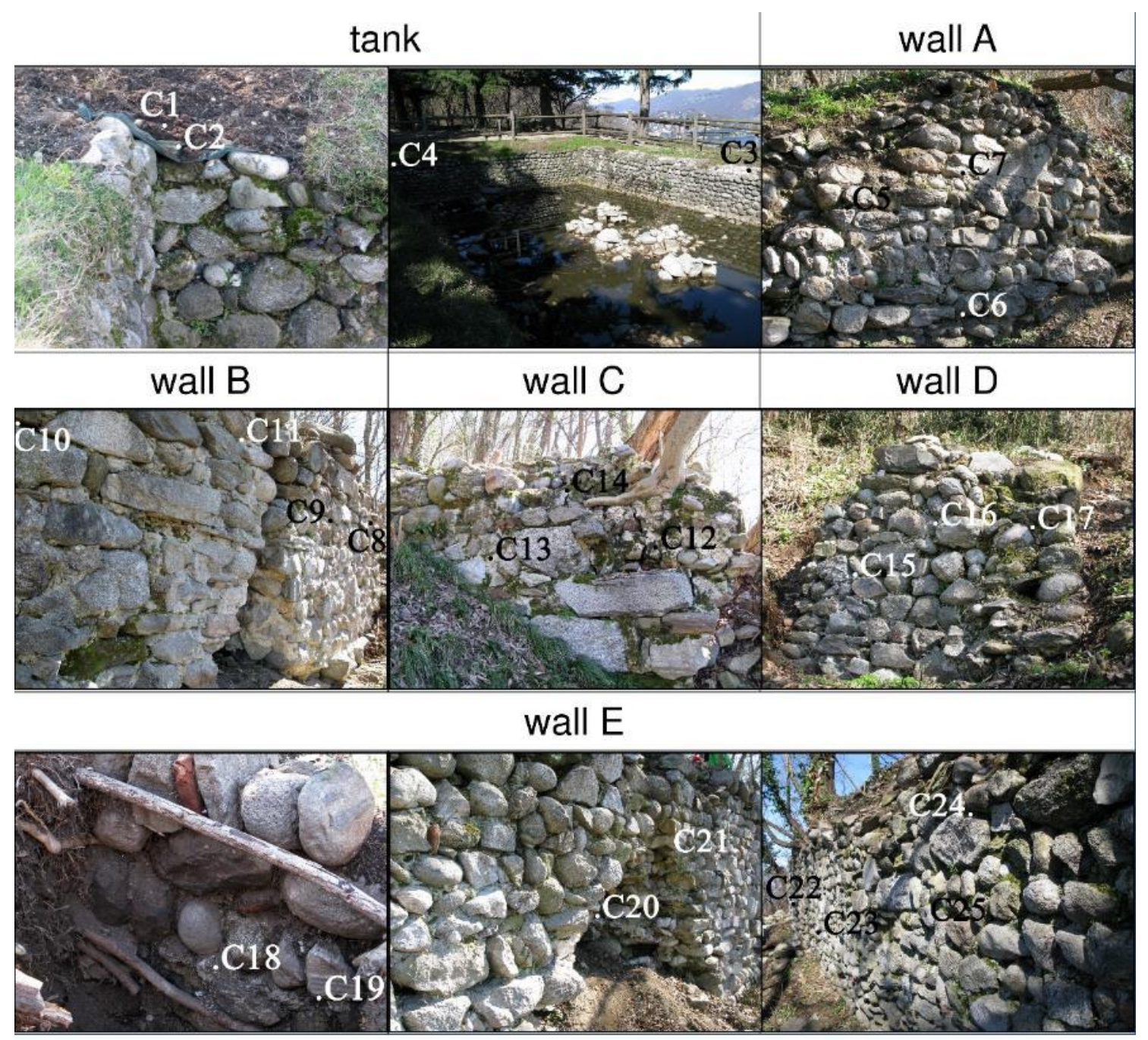

Figure 4 - Provenance of samples 


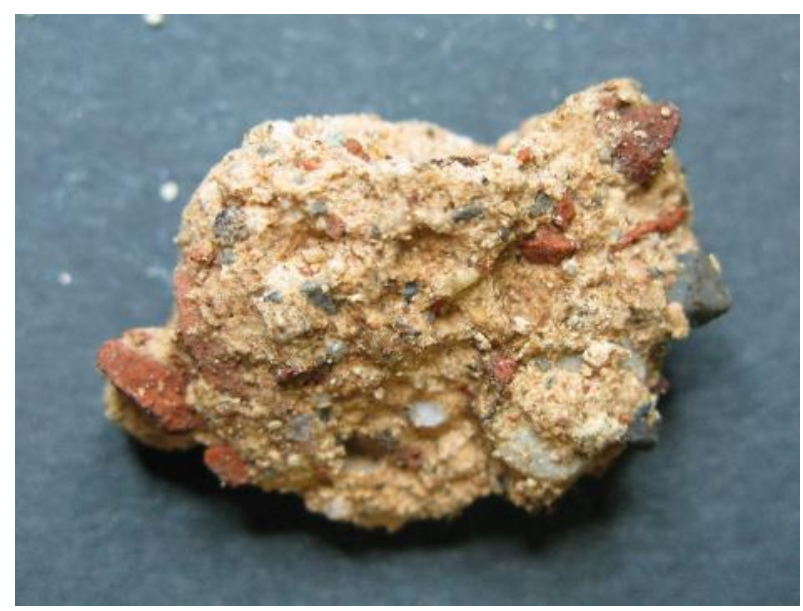

Figure 5 - Sample C2, mortar with cocciopesto

\begin{tabular}{|c|c|c|c|}
\hline structure & sample & description & epoch (as hypothesised by archaeologists) \\
\hline \multirow{4}{*}{ tank } & $\mathrm{C} 1$ & \multirow{4}{*}{ mortar with cocciopesto } & \multirow{2}{*}{ VI-VII century AD } \\
\hline & $\mathrm{C} 2$ & & \\
\hline & $\mathrm{C} 3$ & & \multirow{2}{*}{ probable restoration work, present age } \\
\hline & $\mathrm{C} 4$ & & \\
\hline \multirow{3}{*}{ wall A } & C5 & mortar with coarse aggregate & \multirow{21}{*}{ VI-VII century AD } \\
\hline & C6 & brittle mortar, more compact at the outside & \\
\hline & $\mathrm{C} 7$ & mortar with scarce aggregate & \\
\hline \multirow{4}{*}{ wall B } & $\mathrm{C} 8$ & & \\
\hline & C9 & & \\
\hline & $\mathrm{C} 10$ & & \\
\hline & $\mathrm{C} 11$ & & \\
\hline \multirow{3}{*}{ wall C } & $\mathrm{C} 12$ & & \\
\hline & $\mathrm{C} 13$ & & \\
\hline & $\mathrm{C} 14$ & fine grained mortar, with scarce aggregate & \\
\hline \multirow{3}{*}{ wall D } & $\overline{\mathrm{C} 15}$ & & \\
\hline & $\mathrm{C} 16$ & & \\
\hline & $\mathrm{C} 17$ & & \\
\hline \multirow{2}{*}{ wall E (uphill) } & $\mathrm{C} 18$ & & \\
\hline & C19 & & \\
\hline \multirow{6}{*}{ wall E (downhill) } & $\mathrm{C} 20$ & & \\
\hline & $\mathrm{C} 21$ & & \\
\hline & $\mathrm{C} 22$ & & \\
\hline & $\mathrm{C} 23$ & & \\
\hline & $\mathrm{C} 24$ & & \\
\hline & $\mathrm{C} 25$ & & \\
\hline
\end{tabular}

Table 1 - Description of the mortar samples

\subsection{X-ray Powder Diffraction Analysis}

X-ray diffraction analysis was conducted using a Bruker AXS D8 ADVANCE diffractometer operating at 30kV and $40 \mathrm{~mA}, \mathrm{Cu}-\mathrm{K} \alpha$ radiation $(\lambda=1.5418 \AA)$ monochromated with a graphite monochromator. Scans were collected on powder samples in the range $5-55^{\circ} 2 \theta$; step scan $\Delta 2 \theta=0.02^{\circ}$, counting time $\mathrm{t}=1 \mathrm{~s}$. EVA software (DIFFRACplus EVA) and 
paper-based databases were used to identify the mineral phases in each X-ray powder spectrum, by comparing experimental peaks with reference patterns. The semi-quantitative mineralogical composition of each mineralogical phase detected in the XRD spectrum was calculated, too.

\subsection{Thermal Analysis}

Thermal analysis (TGA/DSC) was performed by means of a NETZSCH STA 409 PC instrument. Samples were placed in alumina crucibles, the temperature program ranged from room temperature to $900^{\circ} \mathrm{C}$, at a heating rate of $10^{\circ} \mathrm{C} \mathrm{min}^{-1}$ under pure nitrogen atmosphere. TG and DSC raw data were corrected on the basis of a background curve.

\subsection{Fourier Transform Infrared Spectroscopy}

FTIR spectra were recorded on KBr pellets (Sigma-Aldrich FTIR Grade) in transmission mode, by a BioRad Excalibur Series FTS 3000 spectrometer (detector DTGS) in the 4000-400 $\mathrm{cm}^{-1}$ range, with a resolution of $4 \mathrm{~cm}^{-1}, 16$ scans.

Pellets were prepared by mixing samples and $\mathrm{KBr}$ in an agate mortar, pouring the mixture in a press and then applying a pressure of 6 ton $/ \mathrm{cm}^{2}$ for 1 minute.

\subsection{Scanning Electron Microscopy and Energy Dispersive X-ray spectroscopy}

The morphology of the different components of the mortars was observed with a FEI/Philips XL30 ESEM. The elemental analyses were performed using an X-ray energy dispersive spectrometer EDX Quantax 400 coupled to SEM. Every sample was observed 'as is' in low vacuum mode (1 torr) at 20kV, by using GSE, BSE and X-Ray detectors.

\subsection{Thin Sections}

Thin sections were prepared following the standard method. A Nikon Eclipse E400 Pol microscope with Nikon Pol objectives was used for the observation.

\section{RESULTS AND DISCUSSION}

All the samples were analyzed in FTIR, TG-DSC and XRD. Some of them, chosen on the basis of their particular features, were observed by means of optical microscopy of thin sections and SEM-EDX.

\subsection{Thin sections}

The observation of thin sections was performed on only one sample for each structure, because it was considered representative of the whole.

The results of the observations are reported in Table 2 and Table 3. 


\begin{tabular}{|l|l|l|l|l|l|}
\hline \multirow{2}{*}{ structure } & \multirow{2}{*}{ sample } & \multicolumn{2}{|l|}{ binder } & \multicolumn{2}{l|}{ cavities } \\
\cline { 3 - 7 } & & composition & texture & shape & size (mm) \\
\hline tank & C2 & calcite (lime) & lump & rounded & 0.5 \\
\hline wall A & C7 & calcite (lime) & lump & irregular & 0.5 \\
\hline wall B & C8 & calcite (lime) & lump & rounded & $0.2-0.6$ \\
\hline wall C & C14 & calcite (lime) & lump & irregular & $0.2-0.8$ \\
\hline wall D & C16 & calcite (lime) & lump & irreg. cracks & $0.1-0.2$ \\
\hline wall E & C20 & calcite (lime) & homogeneous & irregular & $0.2-0.8$ \\
\hline
\end{tabular}

Table 2 - Results of petrographic analysis

\begin{tabular}{|c|c|c|c|c|c|c|c|}
\hline \multirow{2}{*}{ structure } & \multirow{2}{*}{ sample } & \multicolumn{6}{|c|}{ aggregate features } \\
\hline & & clasts & size $(\mathrm{mm})$ & shape & corners & sorting & aggregate $\%$ \\
\hline \multirow{2}{*}{$\operatorname{tank}$} & \multirow{2}{*}{$\mathrm{C} 2$} & quartz (metam.) & 0.8 & equant & subrounded & - & \\
\hline & & brick & 0.4 & equant & subangular & & \\
\hline \multirow{2}{*}{ wall A } & \multirow{2}{*}{$\mathrm{C} 7$} & quartz & $0.1-0.5$ & prismatic & subangular & scarce & \\
\hline & & metam & 1.5 & prismatic & rounded & & \\
\hline \multirow{2}{*}{ wall B } & \multirow{2}{*}{$\mathrm{C} 8$} & quartz (metam.) & $0.1-0.8$ & equant - prism. & angular & medium & low \\
\hline & & muscovite & $0.4-0.6$ & lamellar & angular & & \\
\hline \multirow{3}{*}{ wall C } & \multirow{3}{*}{$\mathrm{C} 14$} & quartz & $0.1-1.0$ & equant & subangular & very scarce & medium \\
\hline & & metamorphic & $0.5-4.1$ & prismatic & subrounded & & \\
\hline & & limestone & $0.8-2.0$ & equant & rounded & & \\
\hline \multirow{3}{*}{ wall D } & \multirow{3}{*}{$\mathrm{C} 16$} & quartz & $0.1-0.3$ & equant & subangular & very scarce & very low \\
\hline & & metamorphic & $0.2-0.8$ & equant & subrounded & & \\
\hline & & limestone & $2.0-5.0$ & equant & rounded & & \\
\hline \multirow{3}{*}{ wall E } & \multirow{3}{*}{$\mathrm{C} 20$} & quartz & $0.1-0.3$ & equant & subangular & scarce & high \\
\hline & & metamorphic & $0.2-9.0$ & equant & subrounded & & \\
\hline & & limestone & $0.5-2.2$ & equant & rounded & & \\
\hline
\end{tabular}

Table 3 - Results of petrographic analysis

Legend: $q z=$ quartz, met. $=$ metamorphic rock fragments, lim. $=$ limestone, mus. $=$ muscovite

The analysis of binder using optical microscopy on thin sections does not allow us to distinguish the presence of a magnesian fraction in the lime. On the contrary, the texture of the binder allows us to differentiate the homogeneous mortars from those containing lumps (always made of calcium carbonate, but clearly different from the surrounding binder).

The aggregate is clearly discriminated by optical microscopy allowing us to separate the lime used as binder from the limestone clasts used as aggregate. In this case the aggregate is always made of natural sand, too. It is quite difficult to understand the provenance of the sand in this region, where the Quaternary glaciers carried out detrital materials from the Alpine range containing igneous and metamorphic silicate rocks from the Basement and sedimentary rocks from the Mesozoic series.

The presence of the cavities, their shape and size, is due to some features of the mix design (binder/aggregate ratio, aggregate shape, amount of water) but could be even strongly affected by the weathering of the mortars during the period of burial. 
Sample C2 includes a hydraulic fraction made of bricks mechanically crushed. Samples C7 and C8 contain a silicate aggregate made of quartz coming from igneous rocks and quartz coming from metamorphic rocks (undulose extinction); clasts of metamorphic rocks contain quartz, plagioclase, feldspar or muscovite. Sample C20 (Figure 6b) (wall E downhill) is different from the other ones featuring high percentage of coarse grained aggregate. Samples C8, C14 (Figure 6a), C16 contain small fragments of wood (size circa $1.0 \mathrm{~mm}$ ), possibly coming from the addition of charcoal to the inorganic aggregate. Samples C14 (Figure 6a), C16, C20 (Figure 6b) contain limestone in the aggregate, marking a different supply of sand. Samples C14 (Figure 6a) and C16 are quite similar, but the aggregate percentage is different.

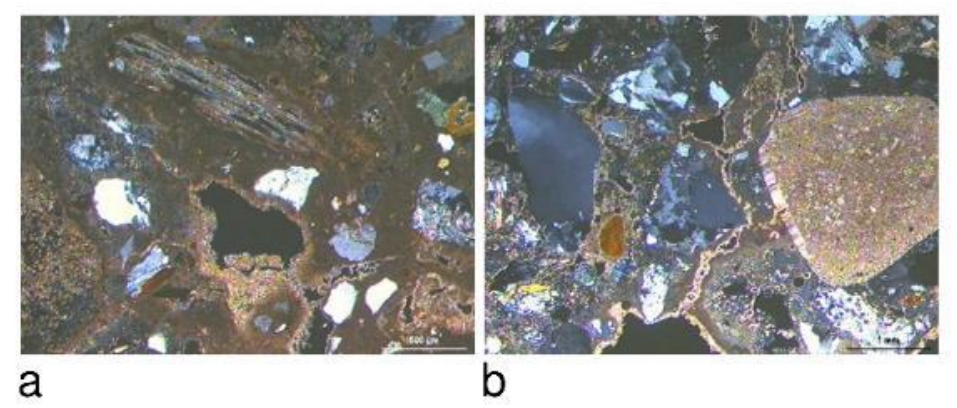

Figure 6 - a: sample C14 - Thin section, cross-polarized light. A lime binder, with irregularly shaped cavities, contains clasts of quartz and metamorphic rock together with a wood fragment (top centre). b: sample C20 - Thin section, cross-polarized light. A lime binder, with cracks coated of secondary calcite crystals, contains rounded clasts of limestone (right), metamorphic rock clasts (centre) and angular crystals of quartz (left)

\subsection{XRD}

In Table 4 X-ray diffraction results are reported. The relative abundance is also shown, on the basis of the intensity of peaks.

Quartz $\left[\mathrm{SiO}_{2}\right]$ and calcite $\left[\mathrm{CaCO}_{3}\right]$ (either magnesian calcite, $\left[(\mathrm{Ca}, \mathrm{Mg}) \mathrm{CO}_{3}\right]$ ) are the most common mineral phases found in each mortar, even if in different relative amounts. For example, samples C3, C7 and C17 are constituted almost exclusively of calcite, while the opposite situation is present in the sample C6. It can also be noted that the sample C23 does not contain quartz. Most of the samples, except for $\mathrm{C} 3, \mathrm{C} 7, \mathrm{C} 15$ and $\mathrm{C} 23$, contain the feldspar albite $\left[\mathrm{NaAlSi}_{3} \mathrm{O}_{8}\right]$ : a peculiar situation can be seen in $\mathrm{C} 24$ and $\mathrm{C} 25$, where it is particularly abundant. Other feldspars can be recognized, as microcline [triclinic $\mathrm{KAlSi}_{3} \mathrm{O}_{8}$ ] and orthoclase [monoclinic $\mathrm{KAlSi}_{3} \mathrm{O}_{8}$ ]. Fillosilicates as serpentine [(Mg, $\left.\mathrm{Fe})_{3} \mathrm{Si}_{2} \mathrm{O}_{5}(\mathrm{OH})_{4}\right]$ and micas (muscovite $\left.\left[\mathrm{KAl}_{3} \mathrm{Si}_{3} \mathrm{O}_{10}(\mathrm{OH}, \mathrm{F})_{2}\right]\right)$ are also common. Six samples $(\mathrm{C} 1, \mathrm{C} 3, \mathrm{C} 4, \mathrm{C} 6, \mathrm{C} 12$, $\mathrm{C} 20)$, especially those coming from the tank, contain little amount of gypsum $\left(\mathrm{CaSO}_{4} \cdot 2 \mathrm{H}_{2} \mathrm{O}\right)$ that could have been added to the raw materials of the mortars, or could be a degradation product [12]. Gypsum was not highlighted by the observation of thin sections because it is difficult to be seen, unless it is greatly abundant. Three samples (C3, C4, C5) include a little amount of aragonite $\left[\mathrm{CaCO}_{3}\right]$, the metastable orthorhombic form of calcium carbonate, less common than calcite and generally found in the shells of molluscs [28-31]. Aragonite is not a common mineral in the area of Baradello, but it could be found in the raw materials that constitute the mortar, due to the presence of shells of gastropods coming from the near Lake Como. Two samples (C7 and C23) have little amounts of dolomite $\left[\mathrm{CaMg}\left(\mathrm{CO}_{3}\right)_{2}\right]$. All the samples coming from wall E (except $\mathrm{C} 23$ ) show the peculiarity of quartz being the most abundant mineral phase. The presence of muscovite, a mineral of the family of micas, in many samples may indicate that the burning of the calcareous stones to prepare the quick lime was done at temperatures lower than $800-900^{\circ} \mathrm{C}$ [18]. 


\begin{tabular}{|c|c|c|c|c|c|c|c|c|c|c|c|}
\hline structure & sample & calcite & aragonite & $\begin{array}{l}\text { magnesian } \\
\text { calcite }\end{array}$ & dolomite & quartz & gypsum & feldspars & phyllosilicates & pyroxenes & other \\
\hline \multirow{4}{*}{$\operatorname{tank}$} & $\mathrm{C} 1$ & +++ & & & & ++ & + & + & & & \\
\hline & $\mathrm{C} 2$ & & & +++ & & +++ & & + & & & \\
\hline & C3 & & + & +++ & & + & + & & & & \\
\hline & $\mathrm{C} 4$ & +++ & + & & & +++ & + & + & + & & \\
\hline \multirow{3}{*}{ wall A } & $\mathrm{C} 5$ & ++ & + & & & +++ & & + & & & \\
\hline & C6 & ++ & & & & +++ & + & ++ & + & & \\
\hline & $\mathrm{C} 7$ & +++ & & & + & + & & & & & \\
\hline \multirow{4}{*}{ wall B } & $\mathrm{C} 8$ & & & +++ & & +++ & & + & + & & \\
\hline & C9 & +++ & & & & +++ & & ++ & + & & + \\
\hline & $\mathrm{C} 10$ & +++ & & & & +++ & & +++ & + & & ++ \\
\hline & C11 & +++ & & & & ++ & & + & + & & \\
\hline \multirow{3}{*}{ wall C } & $\mathrm{C} 12$ & +++ & & & & +++ & + & ++ & + & & \\
\hline & $\mathrm{C} 13$ & & & +++ & & +++ & & + & + & & \\
\hline & C14 & & & +++ & & +++ & & + & + & & \\
\hline \multirow{3}{*}{ wall D } & $\mathrm{C} 15$ & & & +++ & & +++ & & & & $+/-$ & \\
\hline & C16 & & & +++ & & + & & + & + & & \\
\hline & $\mathrm{C} 17$ & +++ & & & & + & & + & & & $+/-$ \\
\hline \multirow{2}{*}{$\begin{array}{ll}\text { wall } & \text { E } \\
\text { (uphill) } & \end{array}$} & C18 & & & +++ & & +++ & & + & & ++ & \\
\hline & C19 & ++ & & & & +++ & & + & & & \\
\hline \multirow{6}{*}{$\begin{array}{l}\text { wall E } \\
\text { (downhill) }\end{array}$} & $\mathrm{C} 20$ & & & +++ & & +++ & $+/-$ & + & + & $+/-$ & \\
\hline & C21 & & & +++ & & +++ & & ++ & + & + & \\
\hline & C22 & & & ++ & & +++ & & ++ & + & & \\
\hline & C23 & +++ & & & + & & & & & & \\
\hline & C24 & +++ & & & & +++ & & +++ & + & + & \\
\hline & C25 & +++ & & & & +++ & & +++ & + & & \\
\hline
\end{tabular}

Table 4 - XRD semiquantitative analysis data.

Legend: +++ very abundant $(>40 \%) ;++$ abundant $(15-40 \%) ;+$ present $(3-15 \%) ;+/-$ scarce $(<3 \%)$

\subsection{FTIR}

The species that have been identified are reported in Table 5.

The presence of calcite and silicates in all the samples, as was evidenced from XRD, was confirmed by FTIR, too. All the spectra exhibit bands between 1430 and $1440 \mathrm{~cm}^{-1}$, characteristic of carbonates and corresponding to asymmetric C$\mathrm{O}$ stretching in carbonate ion. Peaks ascribed to calcite are those at 874 (out-of-plane bending vibration), 713 (in-plane bending vibration), 1798 and $2514 \mathrm{~cm}^{-1}$ (combination modes). It can be seen that some samples (C3, C4, C5, C23 and C24) present another peak near $856 \mathrm{~cm}^{-1}$ (out-of-plane bending vibration), signalling the presence of aragonite, too, partially in agreement with XRD [32-34]. Bands falling in the regions $1200-900$ and $500-400 \mathrm{~cm}^{-1}$ can be generally attributed to the $\mathrm{SiO}_{4}$ tetrahedra of silicates. In most of the samples the peak at $1080 \mathrm{~cm}^{-1}$ can be recognized and attributed to quartz, whose most diagnostic signal is the doublet near 780 and $795 \mathrm{~cm}^{-1}$. Quartz cannot be clearly seen in every sample, but this could probably be due to the fact that its doublet can be overlapped by the peaks of other silicates. Gypsum can be detected in sample C6, which presents its characteristic peaks at 3453, 3408, 1681,1621 (hydroxyl stretching and bending absorption bands), 1147, 1116 (S-O asymmetric stretching vibration bands), 671 and 
$600 \mathrm{~cm}^{-1}$ (S-O bending bands) [33]. This sample shows the highest abundance of gypsum in XRD, too. Finally, the presence of traces of organic matter can be hypothesized in samples C1, C2, C3, C4, C8, C10, C12, C13, C14, C20, where marked peaks in the regions around $2800-2900 \mathrm{~cm}^{-1}$ and $1630 \mathrm{~cm}^{-1}$ can be observed, due to the presence of $\mathrm{C}-\mathrm{H}$ and carbonyl groups.

\begin{tabular}{|c|c|c|c|c|c|c|c|c|}
\hline structure & sample & calcite & aragonite & quartz & silicates & gypsum & nitrates & organic compounds (traces) \\
\hline \multirow{4}{*}{$\operatorname{tank}$} & C1 & * & & * & $*$ & & & * \\
\hline & C2 & $*$ & & * & $*$ & & & * \\
\hline & C3 & * & * & * & * & & & * \\
\hline & $\mathrm{C} 4$ & $*$ & $*$ & $*$ & * & & & $*$ \\
\hline \multirow{3}{*}{ wall A } & $\mathrm{C} 5$ & $*$ & $*$ & & $*$ & & & \\
\hline & C6 & $*$ & & $*$ & $*$ & $*$ & * & \\
\hline & C7 & $*$ & & & * & & & \\
\hline \multirow{4}{*}{ wall B } & $\mathrm{C} 8$ & $*$ & & $*$ & $*$ & & & $*$ \\
\hline & C9 & $*$ & & $*$ & $*$ & & & \\
\hline & C10 & $*$ & & $*$ & * & & & $*$ \\
\hline & C11 & * & & * & * & & & \\
\hline \multirow{3}{*}{ wall $\mathrm{C}$} & $\mathrm{C} 12$ & $*$ & & $*$ & $*$ & & & * \\
\hline & $\mathrm{C} 13$ & $*$ & & $*$ & $*$ & & & $*$ \\
\hline & C14 & $*$ & & $*$ & * & & & $*$ \\
\hline \multirow{3}{*}{ wall D } & $\mathrm{C} 15$ & * & & * & * & & & \\
\hline & C16 & $*$ & & $*$ & $*$ & & & \\
\hline & $\mathrm{C} 17$ & $*$ & & $*$ & * & & & \\
\hline \multirow{2}{*}{ wall E (uphill) } & $\mathrm{C} 18$ & * & & $*$ & * & & & \\
\hline & C19 & $*$ & & $*$ & $*$ & & & \\
\hline \multirow{6}{*}{ wall E (downhill) } & $\mathrm{C} 20$ & $*$ & & $*$ & * & & & $*$ \\
\hline & $\mathrm{C} 21$ & $*$ & & $*$ & $*$ & & & \\
\hline & C22 & $*$ & & $*$ & * & & & \\
\hline & $\mathrm{C} 23$ & * & * & * & * & & & \\
\hline & $\mathrm{C} 24$ & * & * & * & $*$ & & & \\
\hline & $\mathrm{C} 25$ & * & & * & * & & & \\
\hline
\end{tabular}

Table 5 - FTIR data

In Figure 7 and Figure 8 infrared spectra for samples C4 and C6 are shown for example. The spectrum of C4 (Figure 7) presents the typical signals detected in all the samples, i.e. those ascribed to calcite, quartz and silicates. In addition to these, it is possible to note, however, one of the characteristic peaks of aragonite $\left(858 \mathrm{~cm}^{-1}\right)$ and one $\left(1634 \mathrm{~cm}^{-1}\right)$ attributable to organic substances in trace amounts, probably due to the presence of a carbonyl or a carbon double bond group. The spectrum of the sample C6 (Figure 8) is unique in that it has clear signals of gypsum $(3543,3408,1681$, $\left.1621,1147,1116,671,600 \mathrm{~cm}^{-1}\right)$ and a peak $\left(1385 \mathrm{~cm}^{-1}\right)$ generally associated with the presence of nitrates. 


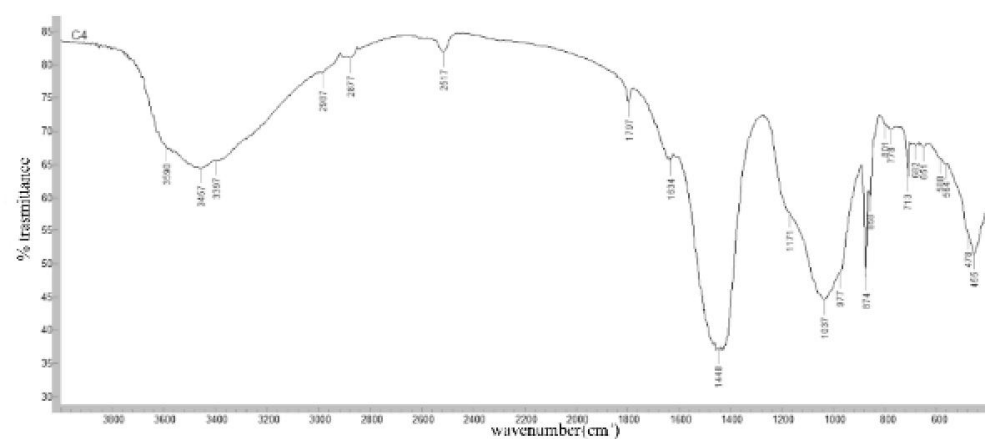

Figure 7 - FTIR spectrum of sample C4 in $\mathrm{KBr}$ (Absorption peaks: calcite: 2517, 1797, 1448, 874, $713 \mathrm{~cm}^{-1}$; aragonite: $858 \mathrm{~cm}^{-1}$; quartz: 801, 778cm silicates: $3590,3457,3397,1037,977,478,455 \mathrm{~cm}^{-1}$; organic compounds: $1634 \mathrm{~cm}^{-1}$ )

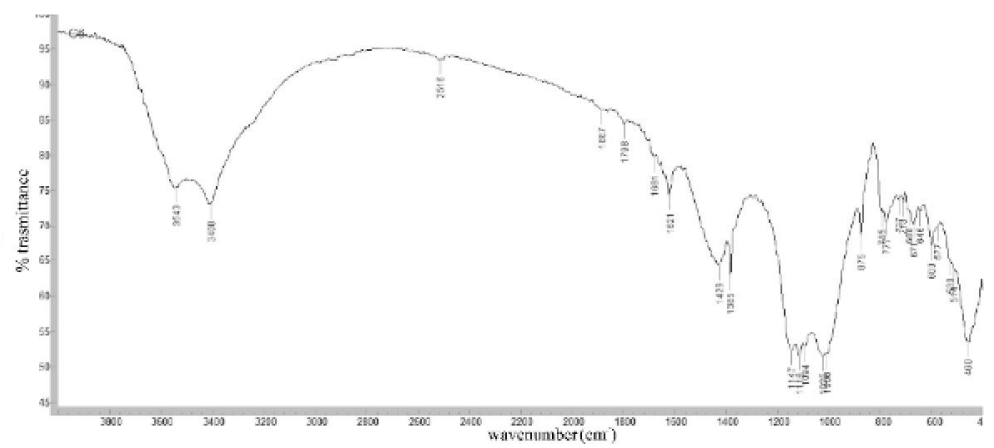

Figure 8 - FTIR spectrum of sample C6 in $\mathrm{KBr}$ (Absorption peaks: calcite: 2516, 1798, 1429, 875, 713 $\mathrm{cm}^{-1}$; quartz: 1094, 795, 777, 515, 460 $\mathrm{cm}^{-1}$; silicates: $1025,1006,530,460 \mathrm{~cm}^{-1}$; gypsum: $3543,3408,1681,1621,1147,1116,671,600 \mathrm{~cm}^{-1}$; nitrates: $1385 \mathrm{~cm}^{-1}$ )

\subsection{TG-DSC}

All samples have been analyzed by thermal analysis (TG and DSC simultaneously).

All of them show the TG signals characteristic of the loss of $\mathrm{CO}_{2}$, due to the decomposition of carbonates. Calcium carbonate generally decomposes between 750 and $850^{\circ} \mathrm{C}$, but its signal falls in different positions depending on the state of crystallization, the presence of other salts or organic additives, the grain size and the atmosphere used for the analysis $[11,16,17,20]$. The temperature of decomposition of calcium carbonate, calculated from DTG (first derivative of TG) curves, can be seen in Table 6 . The position of these peaks shifts from about $650^{\circ} \mathrm{C}$ for polycrystalline calcite, up to about $850^{\circ} \mathrm{C}$ for the monocrystalline form $[35,36]$. In most of the analyzed samples, calcite decomposes at temperatures lower than $850^{\circ} \mathrm{C}$, pointing out the presence of recarbonated lime or impurities, for example magnesian lime or clays. If dolomite is present, a double peak appears at 780 and $860^{\circ} \mathrm{C}[16,20]$. Quartz can be identified from the DSC plot, using an endothermic peak at about $573^{\circ} \mathrm{C}$, corresponding to the transition phase $\alpha \rightarrow \beta$, without loss of mass $[13,16,17]$. This characteristic peak is present in almost all samples except those coming from the tank $(\mathrm{C} 1, \mathrm{C} 2, \mathrm{C} 3$ and C4). Gypsum has two DTG and DSC peaks in the range $120-200^{\circ} \mathrm{C}$ : signals of this type are present in the samples C1, C6, C9, C12 and C24. Other samples have less clear peaks, for example, C3, C5 and C22. Sometimes it can be difficult to distinguish the two peaks, because they can be overlapped, especially depending on the heating rate set (which also influences the temperature where they fall) [37]. The two endothermic DSC peaks correspond, respectively, to the loss of 1.5 molecules of water (at about $138^{\circ} \mathrm{C}$ ) and to the one of the remaining 0.5 molecules [13, 21]. Gypsum may be a product of the sulphation caused by acid rain due to the presence of $\mathrm{H}_{2} \mathrm{SO}_{4}$, or it could have been added directly as a constituent of the binder to improve the features of compactness, hardness and time of setting [13, 21]. Samples C3, C12, C20, C22 and C23 show DTG peaks in the range $300-350^{\circ} \mathrm{C}$, due to dehydroxylation of micaceous 
minerals (in general, the peaks between 200 and $600^{\circ} \mathrm{C}$ are attributed to the loss of structural $\mathrm{OH}^{-}$from micaceous minerals and phyllosilicates) [12]. The peaks associated with micas can also be found around $630^{\circ} \mathrm{C}$, such as those visible in the samples C2, C6, C9, C10, C11, C25 and particularly strong in C3 and C4.

The data obtained from TG were subsequently analysed, using the conventional pattern of temperature ranges reported in the literature $[9,13,16,17,24]$ :

- room temperature to $120^{\circ} \mathrm{C}$ : loss of adsorbed water from the mortar;

- 120 to $200^{\circ} \mathrm{C}$ : loss of water from hydrated salts;

- 200 to $600^{\circ} \mathrm{C}$ : loss of structurally bound water in hydraulic compounds (aluminosilicates hydrates, minerals CSH, micas, etc.);

- $>600^{\circ} \mathrm{C}$ : loss of $\mathrm{CO}_{2}$ from the decomposition of carbonates.

The resulting data can be seen in Table 7 .

\begin{tabular}{|c|c|c|}
\hline structure & sample & $\begin{array}{l}\text { temperature of } \mathrm{CO}_{2} \text { loss } \\
\text { in DTG curves }\left({ }^{\circ} \mathrm{C}\right)\end{array}$ \\
\hline \multirow{4}{*}{$\operatorname{tank}$} & $\mathrm{C} 1$ & 806 \\
\hline & $\mathrm{C} 2$ & 792 \\
\hline & $\mathrm{C} 3$ & 780 \\
\hline & $\mathrm{C} 4$ & 770 \\
\hline \multirow{3}{*}{ wall A } & $\mathrm{C} 5$ & 804 \\
\hline & C6 & 794,878 \\
\hline & C7 & 823 \\
\hline \multirow{4}{*}{ wall B } & C8 & 783 \\
\hline & C9 & 778 \\
\hline & $\mathrm{C} 10$ & 786 \\
\hline & C11 & 809 \\
\hline \multirow{3}{*}{ wall C } & $\mathrm{C} 12$ & 786 \\
\hline & C13 & 793 \\
\hline & C14 & 786 \\
\hline \multirow{3}{*}{ wall D } & $\mathrm{C} 15$ & 849 \\
\hline & C16 & 817 \\
\hline & $\mathrm{C} 17$ & 818 \\
\hline \multirow{2}{*}{ wall E (uphill) } & $\mathrm{C} 18$ & 778 \\
\hline & C19 & 814 \\
\hline \multirow{6}{*}{ wall E (downhill) } & $\mathrm{C} 20$ & 783 \\
\hline & $\mathrm{C} 21$ & 820 \\
\hline & $\mathrm{C} 22$ & 782 \\
\hline & $\mathrm{C} 23$ & 781 \\
\hline & $\mathrm{C} 24$ & 787 \\
\hline & $\mathrm{C} 25$ & 793 \\
\hline
\end{tabular}

Table 6 - Temperature of decomposition of calcium carbonate 


\begin{tabular}{|c|c|c|c|c|c|c|}
\hline \multirow{2}{*}{ structure } & \multirow{2}{*}{ sample } & \multicolumn{5}{|c|}{ weight loss in each temperature range $\left({ }^{\circ} \mathrm{C}\right)$} \\
\hline & & $<120(\%)$ & $120-200(\%)$ & $200-600(\%)$ & $>600(\%)$ & total loss (\%) \\
\hline \multirow{4}{*}{$\operatorname{tank}$} & $\mathrm{C} 1$ & 23.27 & 7.34 & 3.53 & 17.51 & 51.65 \\
\hline & $\mathrm{C} 2$ & 2.46 & 1.57 & 3.77 & 23.02 & 30.81 \\
\hline & $\mathrm{C} 3$ & 2.81 & 2.27 & 6.87 & 18.36 & 30.30 \\
\hline & C4 & 5.72 & 2.84 & 5.90 & 12.15 & 26.61 \\
\hline \multirow{3}{*}{ wall $\mathrm{A}$} & $\mathrm{C} 5$ & 3.33 & 0.92 & 4.94 & 19.71 & 28.90 \\
\hline & C6 & 1.94 & 1.89 & 3.99 & 5.62 & 13.45 \\
\hline & C7 & 0.81 & 0.38 & 3.41 & 36.08 & 40.67 \\
\hline \multirow{4}{*}{ wall B } & C8 & 2.42 & 1.98 & 4.99 & 16.33 & 25.71 \\
\hline & C9 & 1.80 & 0.90 & 2.94 & 12.55 & 18.20 \\
\hline & $\mathrm{C} 10$ & 1.65 & 1.08 & 3.41 & 12.20 & 18.35 \\
\hline & C11 & 2.06 & 1.26 & 4.55 & 21.24 & 29.10 \\
\hline \multirow{3}{*}{ wall C } & $\mathrm{C} 12$ & 6.60 & 1.93 & 4.29 & 11.74 & 24.56 \\
\hline & $\mathrm{C} 13$ & 3.04 & 1.32 & 4.14 & 19.33 & 27.82 \\
\hline & C14 & 2.30 & 1.30 & 3.55 & 14.58 & 21.73 \\
\hline \multirow{3}{*}{ wall D } & C15 & 0.49 & 0.23 & 2.71 & 32.46 & 35.88 \\
\hline & C16 & 1.07 & 0.32 & 3.11 & 32.90 & 37.41 \\
\hline & C17 & 1.36 & 0.37 & 2.70 & 30.93 & 35.36 \\
\hline \multirow{2}{*}{ wall E (uphill) } & C18 & 0.50 & 0.14 & 1.60 & 13.69 & 15.93 \\
\hline & C19 & 2.44 & 0.31 & 2.05 & 18.32 & 23.11 \\
\hline \multirow{6}{*}{ wall E (downhill) } & $\mathrm{C} 20$ & \begin{tabular}{|l|l|}
1.64 &
\end{tabular} & 0.55 & 1.95 & 8.47 & 12.62 \\
\hline & $\mathrm{C} 21$ & 1.23 & 0.64 & 4.19 & 16.73 & 22.79 \\
\hline & $\mathrm{C} 22$ & 1.11 & 0.37 & 2.79 & 9.76 & 14.04 \\
\hline & $\mathrm{C} 23$ & 1.93 & 0.50 & 4.12 & 14.69 & 21.23 \\
\hline & $\mathrm{C} 24$ & 1.33 & 0.62 & 3.49 & 13.56 & 19.00 \\
\hline & $\mathrm{C} 25$ & 1.65 & 0.47 & 3.18 & 10.92 & 16.22 \\
\hline
\end{tabular}

Table 7 - Mass loss according to the conventional pattern of temperature ranges

It can be seen that the total mass loss (\%) ranges from $12.6(\mathrm{C} 20)$ to $51.6(\mathrm{C} 1)$.

The observation of thin sections showed that all samples have a carbonatic binder, but those from wall C, wall D and wall $\mathrm{E}$ have a carbonatic aggregate, too. This characteristic makes it impossible to calculate, for these samples, the binder/aggregate, defined as the ratio between the calcite (determined by the loss of $\mathrm{CO}_{2}$ ) and the rest of the sample. B/A was calculated, and reported in Table 8, only for samples coming from tank, wall A and wall B.

The index of hydraulicity of the mortar, defined as the ratio between the amount of $\mathrm{CO}_{2}$ lost above $600^{\circ} \mathrm{C}$ from carbonates and the amount of $\mathrm{H}_{2} \mathrm{O}$ linked to hydraulic compounds and lost between 200 and $600^{\circ} \mathrm{C}[10,16,20,38]$, was calculated for all the samples. Consequently, higher $\mathrm{CO}_{2} / \mathrm{H}_{2} \mathrm{O}$ ratios correspond to less hydraulic mortars, and vice versa. The results are shown in Table 8 . 


\begin{tabular}{|c|c|c|c|c|}
\hline structure & sample & $\mathrm{CO}_{2} / \mathrm{H}_{2} \mathrm{O}$ & $\mathrm{B} / \mathrm{A}$ & $\%$ calcite \\
\hline \multirow{4}{*}{$\operatorname{tank}$} & $\mathrm{C} 1$ & 4.96 & 1.08 & 51.91 \\
\hline & $\mathrm{C} 2$ & 6.11 & 1.16 & 53.66 \\
\hline & $\mathrm{C} 3$ & 2.67 & 0.75 & 42.96 \\
\hline & $\mathrm{C} 4$ & 2.06 & 0.41 & 29.31 \\
\hline \multirow{3}{*}{ wall A } & $\mathrm{C} 5$ & 3.99 & 0.86 & 46.36 \\
\hline & C6 & 1.41 & 0.15 & 13.04 \\
\hline & C7 & 10.58 & 4.79 & 82.71 \\
\hline \multirow{4}{*}{ wall B } & C8 & 3.28 & 0.61 & 38.06 \\
\hline & C9 & 4.27 & 0.41 & 29.07 \\
\hline & $\mathrm{C} 10$ & 3.57 & 0.39 & 28.21 \\
\hline & C11 & 4.67 & 0.97 & 49.32 \\
\hline \multirow{3}{*}{ wall C } & $\mathrm{C} 12$ & 2.74 & \multirow{3}{*}{ n.d.* } & 28.58 \\
\hline & C13 & 4.67 & & 45.33 \\
\hline & C14 & 4.11 & & 33.94 \\
\hline \multirow{3}{*}{ wall D } & $\mathrm{C} 15$ & 11.99 & \multirow{3}{*}{ n.d.* } & 74.18 \\
\hline & $\mathrm{C} 16$ & 10.56 & & 75.63 \\
\hline & $\mathrm{C} 17$ & 11.47 & & 71.31 \\
\hline \multirow{2}{*}{ wall E (uphill) } & $\mathrm{C} 18$ & 8.55 & \multirow{8}{*}{ n.d.* } & 31.30 \\
\hline & C19 & 8.95 & & 42.70 \\
\hline \multirow{6}{*}{ wall E (downhill) } & C20 & 4.34 & & 19.59 \\
\hline & $\mathrm{C} 21$ & 4.00 & & 38.52 \\
\hline & $\mathrm{C} 22$ & 3.49 & & 22.44 \\
\hline & C23 & 3.56 & & 34.06 \\
\hline & C24 & 3.88 & & 31.25 \\
\hline & $\mathrm{C} 25$ & 3.44 & & 25.25 \\
\hline
\end{tabular}

Table 8 - index of hydraulicity, binder/aggregate ratio and calcite $\%$ obtained by TA results Legend: n.d. = value not determined, *see text for details

Some authors classified 'true' lime mortars as having $\mathrm{CO}_{2} / \mathrm{H}_{2} \mathrm{O}$ ratios higher than 10 , hydraulic lime mortars between 4 and 10 and pozzolanic mortars $<3[10,12,16,17]$. In our study, samples $\mathrm{C} 7, \mathrm{C} 15, \mathrm{C} 16$ and $\mathrm{C} 17$ have $\mathrm{CO}_{2} / \mathrm{H}_{2} \mathrm{O}$ ratios exceeding 10, so they can be considered as true lime mortars. Most of the others range between 3 and 5, so they can be classified as hydraulic. It is generally difficult to recognise hydraulic lime, but its presence is compatible with an attested use in this region. Quarries of hydraulic lime can be found about $20 \mathrm{~km}$ East from the Baradello Castle, in the area near the small lakes of Brianza region where the Upper Cretaceous marly limestone formation called 'Scaglia Lombarda' outcrops.

The particularity of the sample C6 is outstanding, with its very low ratio (1.41), probably because of its content in gypsum, as evidenced also by XRD and FTIR analysis. Its particular composition, in fact, generates a loss of $\mathrm{CO}_{2}$ equal to only $5.62 \%$ by weight, giving a percentage of calcite in the sample of $13.04 \%$ and, consequently, $\mathrm{B} / \mathrm{A}$ and $\mathrm{CO}_{2} / \mathrm{H}_{2} \mathrm{O}$ ratios particularly low. The structure where $\mathrm{C} 6$ was taken has been buried for centuries, so it can be excluded that the presence of gypsum is due to sulphation phenomena for exposition to air pollutants, but rather to a deliberate addition to the binder. Archaeologists did not observe macroscopic differences in this part of wall, so they cannot assert the presence of a work of conservation during centuries, but they cannot exclude this hypothesis a priori. Its peculiar 
composition, so different from those of the other samples taken from the same structure, could suggest that C6 was a replacement done during a small work of conservation. The use of gypsum has never been attested before in samples of masonry mortars from Lombardy, whilst it was found in renderings or decorative plasters [39].

Samples C3, C4 and C12 have ratios $<3$. The first two samples come from the tank and present a high loss of mass between 200 and $600^{\circ} \mathrm{C}$, maybe related to the presence of visible cocciopesto. For what concerns sample C12, it just seems quite poor in calcite.

The numerical results can be better seen in Figure 9, Figure 10 and Figure 11.

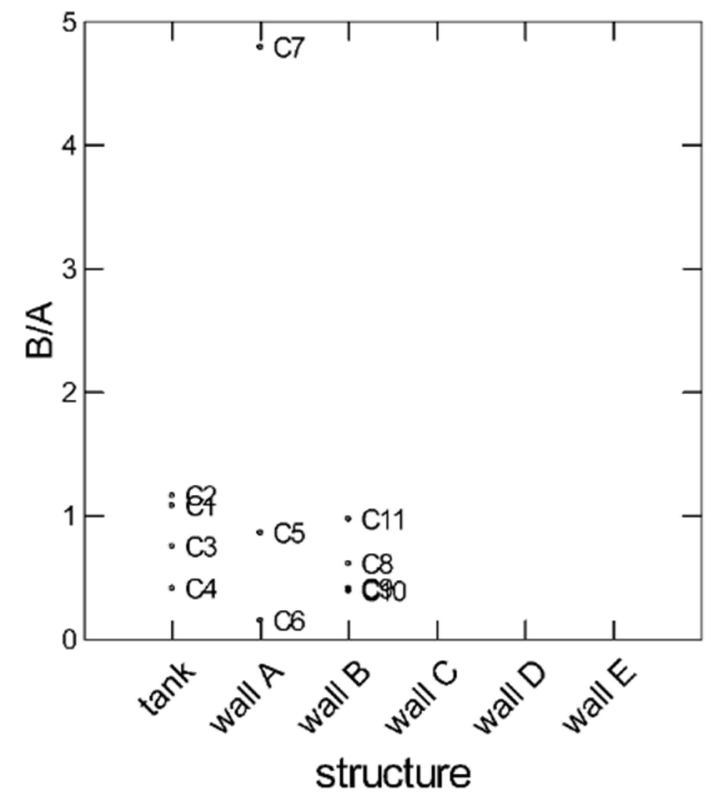

Figure $9-\mathrm{B} / \mathrm{A}$ ratio relative to the different structures

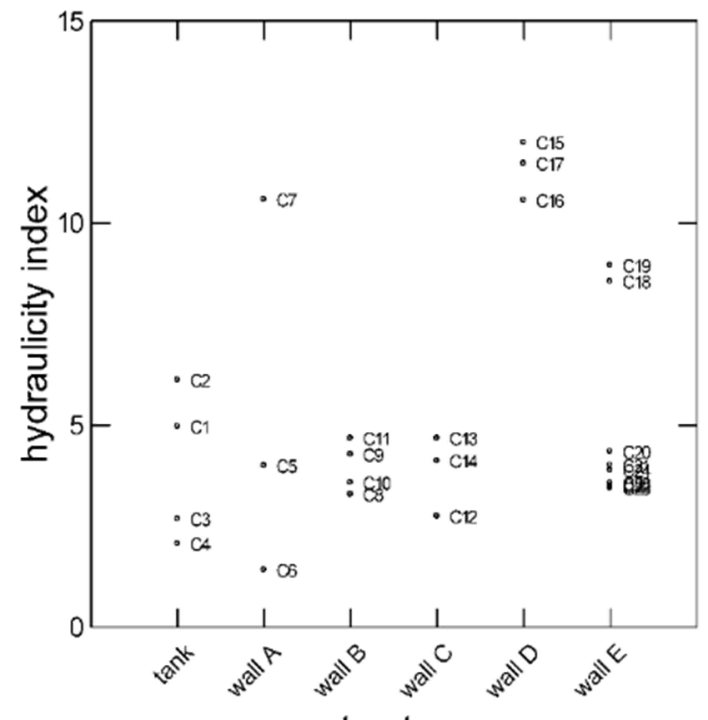

structure

Figure 10 - Hydraulicity index relative to the different structures 

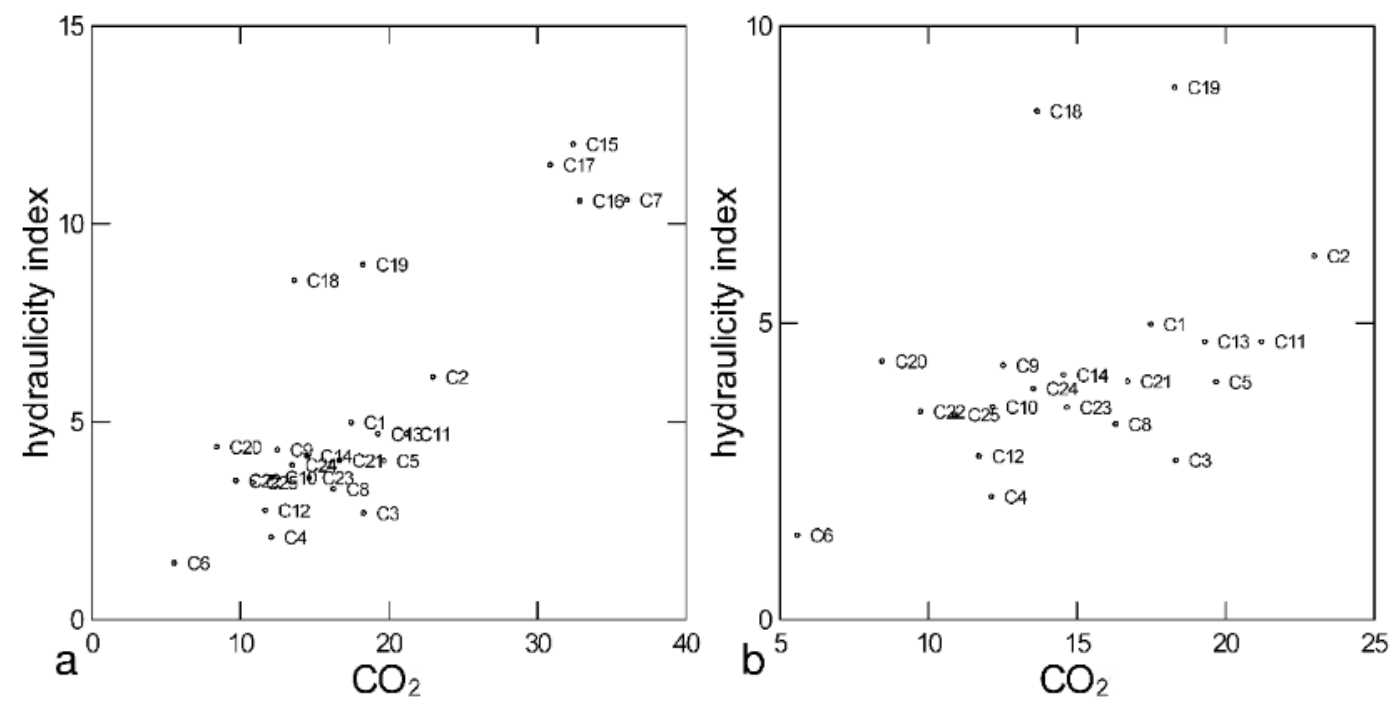

Figure 11 - hydraulicity index vs. $\mathrm{CO}_{2}$ - a: whole graph; b: zoom on the central area

Figure 9 shows the binder/aggregate ratio of samples depending on the structure of provenance and referring only to those without a carbonatic aggregate. A substantial homogeneity inside every structure emerges, except for wall A, which presents very different samples. Archaeologists classified C7 (constituted of calcite for nearly 83\%) as a repairing mortar and this can be confirmed by its peculiar composition. As already said, C6 presents the peculiarity of containing a relevant amount of gypsum and scarce calcite: there is no clear evidence from the archaeological inspection, but it cannot be excluded that it is another sample related to an ancient work of maintenance. Thus, C5 seems to be the only sample of wall A constituted by original materials and can be related to the samples coming from wall $\mathrm{B}$, in particular with samples $\mathrm{C} 8$ and $\mathrm{C} 11$. Wall $\mathrm{A}$ and wall B own many similar characteristics from the archaeological point of view and they are classified as coeval.

For what concerns the tank, it can be seen that samples $\mathrm{C} 1$ and $\mathrm{C} 2$, taken in the corner near to the Hexagonal Tower, are nearly overlapped, differently from samples C3 and C4, taken on the side toward the Tower of the Castle.

In Figure 11 (see Figure 11a for the whole graph and Figure 11b for a zoom on the central area, where many samples were overlapped) the hydraulicity index is shown, vs. the \% amount of $\mathrm{CO}_{2}$, making the classification of samples immediately clear, according both to their coefficient of hydraulicity and their content in carbonates [16, 17]. The peculiarity of the structure named wall $\mathrm{D}$ is to have mortars with a marked content in carbonates. It is now possible to see how the sample C6 has the most hydraulic composition, i.e. the lowest hydraulic index. The samples coming from the tank tend to group according to the side to which they belonged (C1-C2 vs. C3-C4), as was seen from B/A ratios. Finally, it is interesting to note how the samples from wall E are distributed: C18 and C19, taken uphill, are much more aerial than those taken downhill. The archaeologists attributed this structure to one only construction campaign, but these results point towards the hypothesis of distinct workdays, or the simultaneous work of two groups with different experiences and procedures of building.

The same considerations are evident in Figure 10, where the hydraulicity vs. the structure of provenance is shown. Finally, the presence of peculiar peaks of gypsum, quartz and calcite in DSC curves is summed up in Table 9. 


\begin{tabular}{|c|c|c|c|c|}
\hline structure & sample & $\begin{array}{l}\text { doublet } 120-200^{\circ} \mathrm{C} \\
\text { (gypsum) }\end{array}$ & $\begin{array}{l}573^{\circ} \mathrm{C} \\
\text { (quartz) }\end{array}$ & $\begin{array}{l}750-850^{\circ} \mathrm{C} \\
\text { (calcite) }\end{array}$ \\
\hline \multirow{4}{*}{$\operatorname{tank}$} & $\mathrm{C} 1$ & & & $*$ \\
\hline & $\mathrm{C} 2$ & & & $*$ \\
\hline & $\mathrm{C} 3$ & & & $*$ \\
\hline & $\mathrm{C} 4$ & & & $*$ \\
\hline \multirow{3}{*}{ wall A } & $\mathrm{C} 5$ & & $*$ & $*$ \\
\hline & C6 & $*$ & $*$ & $*$ \\
\hline & C7 & & & $*$ \\
\hline \multirow{4}{*}{ wall B } & $\mathrm{C} 8$ & & $*$ & * \\
\hline & C9 & * & * & * \\
\hline & $\mathrm{C} 10$ & & $*$ & $*$ \\
\hline & C11 & & * & * \\
\hline \multirow{3}{*}{ wall C } & $\mathrm{C} 12$ & $*$ & $*$ & $*$ \\
\hline & $\mathrm{C} 13$ & & * & $*$ \\
\hline & C14 & & $*$ & $*$ \\
\hline \multirow{3}{*}{ wall D } & $\mathrm{C} 15$ & & $*$ & $*$ \\
\hline & C16 & & $*$ & $*$ \\
\hline & $\mathrm{C} 17$ & & * & * \\
\hline \multirow{2}{*}{ wall E (uphill) } & $\mathrm{C} 18$ & & $*$ & $*$ \\
\hline & C19 & & * & * \\
\hline \multirow{6}{*}{ wall E (downhill) } & $\mathrm{C} 20$ & & $*$ & $*$ \\
\hline & $\mathrm{C} 21$ & & * & * \\
\hline & $\mathrm{C} 22$ & & * & * \\
\hline & $\mathrm{C} 23$ & & * & * \\
\hline & $\mathrm{C} 24$ & $*$ & $*$ & $*$ \\
\hline & $\mathrm{C} 25$ & & * & * \\
\hline
\end{tabular}

Table 9 - Presence of peculiar peaks in DSC curves

\subsection{SEM-EDX}

A selection of samples was observed and analysed using SEM-EDX.

A SEM image and EDX map of sample C3 (tank) is shown in Figure 12, where fragments of cocciopesto, rich of Al, Si, $\mathrm{K}$ and $\mathrm{Fe}$, can be seen.

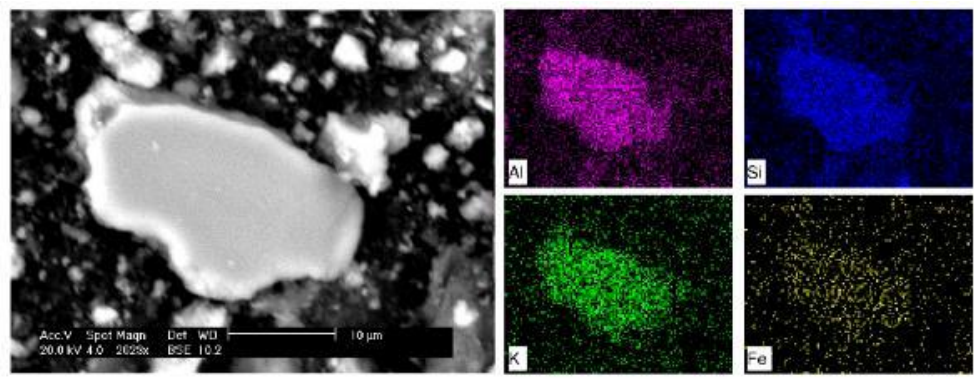

Figure 12 - SEM images and EDX distribution maps of $\mathrm{Al}, \mathrm{Si}, \mathrm{Fe}$ and $\mathrm{K}$ (clockwise from upper left) of cocciopesto fragments in sample $\mathrm{C} 3$ 
For what concerns sample C6 (wall A), where gypsum was detected by all analytical techniques, its presence is confirmed by SEM-EDX, too. Gypsum aggregates have ‘cloudy' (Figure 13) or needle-like (Figure 14) shapes, as shown by the EDX map, where sulphur is clearly accumulated and associated with calcium.
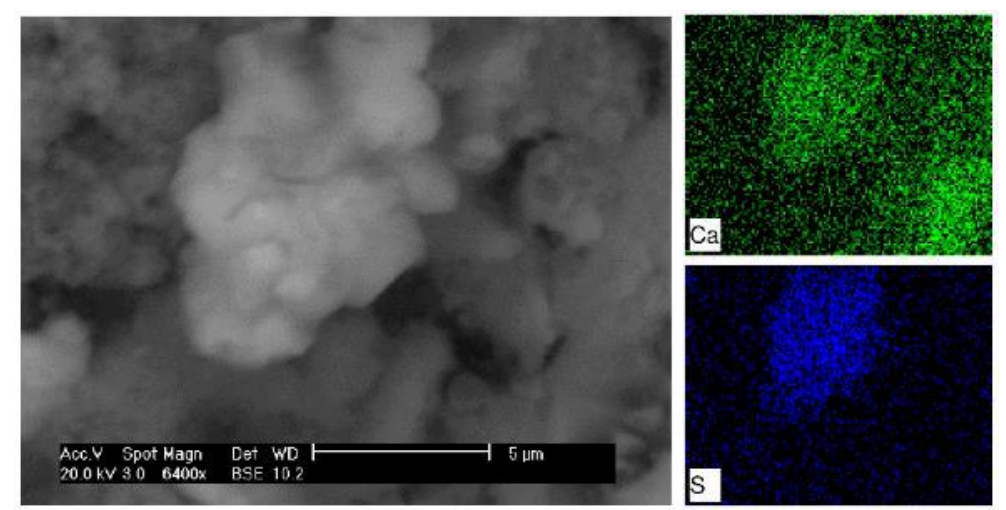

Figure 13 - SEM images and EDX elemental maps of $\mathrm{Ca}$ and $\mathrm{S}$ of 'cloudy' gypsum crystals in sample C6

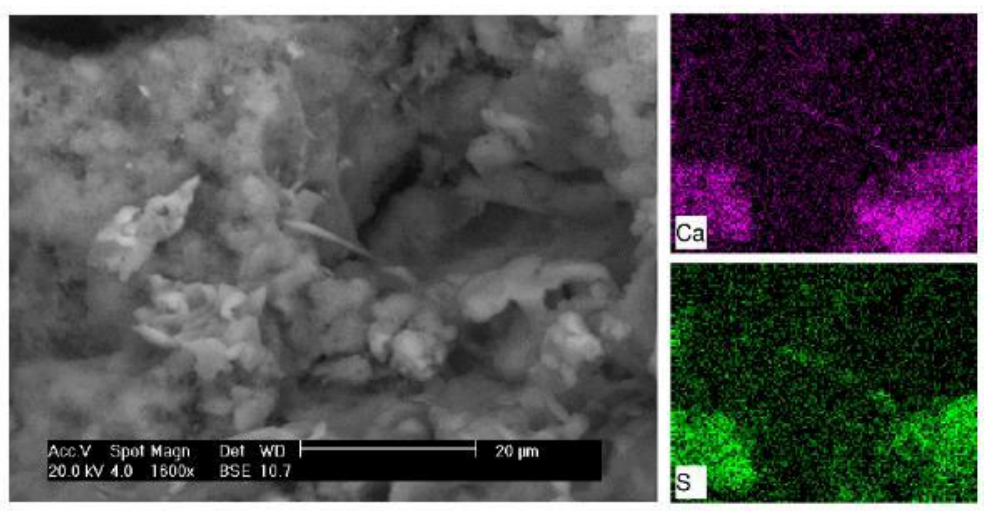

Figure 14 - SEM images and EDX elemental maps of $\mathrm{Ca}$ and $\mathrm{S}$ of needle like gypsum crystals in sample $\mathrm{C} 6$

All the matrices of the mortars are, obviously, rich of calcium and magnesium, as can be seen from XRD, too, which pointed out the presence of pure calcitic and calcitic-magnesian limes. Most of the samples present a considerable amount of silicon, aluminium, and potassium, coming from the silicates constituting the aggregate dispersed in the binder. Some samples contain particles rich of copper and titanium, too.

\section{CONCLUSIONS}

The 'traditional' techniques showed, in this work, the existence of differences between groups of structures, but the thermal analysis was actually discriminating. The various structures were, in fact, characterized by the index of hydraulicity and, except for the mortars with carbonate aggregate, by the binder/aggregate ratio. In particular, the coupling of index of hydraulicity and \% $\%$ 2 revealed the presence of patterns bound to the different structures. All these values were obtained by thermal analysis, which proved to be the most meaningful techniques to evidence a possible building chronology.

It is, in fact, generally difficult to obtain comparable results when it comes to mortars, because of their specific heterogeneity and variability, and the use of different analytical techniques is often the only way to have a global vision of mortars, to classify them and to recognize groups. 
The analyses of samples from Baradello site generally confirmed the hypotheses of the archaeologists, showing a common homogeneity between the materials used in the same structure, while some differences emerged between the castle walls. The results stressed the peculiarity of the tank, whose mortars contain mechanically crushed bricks known as 'cocciopesto': some small differences emerged between the samples, confirming the hypotheses made by the archaeologists concerning subsequent integrations. In addition to the results of thermal analysis, it can also be observed that samples C3 and C4, related to a recent (19th or 20th century) maintenance work contain traces of aragonite, which is not present in $\mathrm{C} 1$ and $\mathrm{C} 2$.

Wall A, B, C, D and E were classified by archaeologist as ascribable to the same building epoch, between 6th and 7th century AD, since they all presented similar characteristics at a macroscopic analysis. The analyses showed that they all have an aggregate consisting of natural sand, but A and B contain only silicate sands, while C, D and E include also carbonate sands, suggesting a different source of supply for raw materials. It is worth to remember that the Baradello Castle site lies on a geological overthrust connecting Miocene quartz sandstones and conglomerates (Gonfolite) southbound, and Lower Jurassic limestones (Calcari selciferi lombardi) northbound: the sand available in these two geological areas is quite dissimilar. Thus, the different composition of raw materials used for the aggregate is completely coherent with the geology of the region and point towards two different areas of material supply and two different moments of construction, at least.

It can also be noted that magnesian lime is nearly absent from wall A and B (except for sample C8), whilst it is more diffuse in wall C, D and E. The nearest source of magnesian lime can be found in the area of Valmadrera, in the socalled 'Triangolo Lariano', the region between the two branches of the Lake Como (about 25 km eastward). A close relationship between Como and this region in Roman and Early Medieval ages is well documented and was eased by the presence of a pedemountain road connecting Como to Erba and Lecco.

Wall A is, by far, the most heterogeneous structure. Sample C5 can be considered as an original ancient mortar; C6 is the only one sample in which all the techniques evidenced the presence of gypsum added to lime and can be identified as a repair mortar. Local sources of gypsum can be found on the Lake Como shores (Nobiallo, near Menaggio) nearly $35 \mathrm{~km}$ north from the Baradello site.

Concerning sample C7, thermal analysis showed its different characteristics respect to the other samples in the same structure. The presence of white lumps inside, as seen in thin sections, suggested a different dating, probably due to another work of integration following the construction. In addition, this is one of the only two samples showing traces of dolomite.

Wall B is more homogeneous and can be considered as coeval with wall A from an archaeological evaluation, because they share many characteristics. In particular, thermal analysis evidenced that samples $\mathrm{C} 8$ and $\mathrm{C} 11$ have a composition similar to C5, which can be identified as an original material of wall A. All the mortars of wall B can be considered as hydraulic according to the index calculated by means of thermal analysis. It is generally not easy to recognise hydraulic lime, but its use is attested as widespread in this area. Sources of hydraulic lime can be found in the area of the small lakes of Brianza, between Como and Lecco.

Wall $\mathrm{C}$ belongs to the second group of structures, together with wall $\mathrm{D}$ and $\mathrm{E}$. As already said, they contain both silicatic and carbonatic aggregate: the first can probably come from the surroundings of the Castle, the second from the area of Cernobbio ( $5 \mathrm{~km}$ northern). A slight difference between $\mathrm{C} 12$ and C13-C14 can be seen in thermal analysis: this can be related to the presence of traces of added gypsum in C12 and the use of magnesian lime (as seen from XRD analysis) in C13 and C14, instead of calcitic lime as in C12. 
Wall D also showed in TG-DSC a low hydraulicity and a particular richness in carbonatic components, both in the binder and, as already said, in the aggregate (as seen from thin sections). It seems to have been built with a different technique, as observed from the different kind of raw materials used, even if there no differenced were evidenced by the archaeological point of view.

Coming to wall E, thermal analysis seemed to support that the samples taken uphill are less hydraulic than those taken downhill. The archaeologists classified this whole structure as built in the same period but, considering the results of these analyses, different phases of construction cannot be excluded.

Summing up the obtained results, a general distinction can be observed between the group constituted by wall A and B and that of wall C, D and E. Within this second group, thermal analysis also highlighted that wall D is clearly different from $\mathrm{C}$ and $\mathrm{E}$. The same technique contributed to show that some structures, substantially homogeneous, were reshaped with some integration after their construction.

The different binders and aggregates used, coming from different quarries, can thus suggest the existence of various moments of construction, with an expansion of the built structures. From the archaeological point of view, it was common in Early Middle Ages to observe a technique of construction with different teams of builders, working simultaneously at different structures under the guidance of a supervisor, using different techniques and raw materials coming from different areas or materials of reuse.

\section{Acknowledgements}

The research has been conducted by Musei Civici di Como in collaboration with Università di Padova, Università di Milano Bicocca, Università dell'Insubria - Como. Under ministerial concession, the direction of archaeological excavation is entrusted to G.P. Brogiolo, L. Castelletti, I. Nobile. The project has been financed by Regione Lombardia and Comune di Como.

\section{REFERENCES}

[1] D. Miriello, A. Bloise, G.M. Crisci, C. Apollaro, A. La Marca, Characterisation of archaeological mortars and plasters from Kyme (Turkey), Journal of Archaeological Science 38 (2011) 794-804.

[2] M.P. Riccardi, P. Duminuco, C. Tomasi, P. Ferloni, Thermal, microscopic and X-ray diffraction studies on some ancient mortars, Thermochimica Acta 321 (1998) 207-214.

[3] J. Elsen, Microscopy of historic mortars - a review, Cement and Concrete Research 36 (2006) 1416-1424.

[4] M. Vendrell-Saz, S. Alarcon, J. Molera, M. Garcia-Valles, Dating ancient lime mortars by geochemical and mineralogical analysis, Archaeometry 38 (1996) 143-149.

[5] P. Bruno, D. Calabrese, M. Di Pierro, A. Genga, C. Laganara, D.A.P. Manigrassi, A. Traini, P. Ubbriaco, Chemicalphysical and mineralogical investigation on ancient mortars from the archaeological site of Monte Sannace (BariSouthern Italy), Thermochimica Acta 418 (2004) 131-141.

[6] L. Rampazzi, A. Pozzi, A. Sansonetti, L. Toniolo, B. Giussani, A chemometric approach to the characterisation of historical mortars, Cement and Concrete Research 36 (2006) 1108-1114.

[7] L. Rampazzi, D. Monticelli, R. Verga, L. Toniolo, A new microwave-assisted approach to the chemical analysis of mortars, Annali Di Chimica 93 (2003) 315-320. 
[8] R. Bugini, S. Della Torre, A. Pozzi, L. Rampazzi, A. Sansonetti, Classification of multi-layered plaster in St. Abbondio Cloister at Como, Italy: an analytical tool for architectural archaeology, Materiales De Construccion 56 (2006) 5-16.

[9] C. Genestar, C. Pons, A. Mas, Analytical characterisation of ancient mortars from the archaeological Roman city of Pollentia (Balearic Islands, Spain), Analytica Chimica Acta 557 (2006) 373-379.

[10] A. Duran, M.D. Robador, M.C. Jimenez de Haro, V. Ramirez-Valle, Study by thermal analysis of mortars belonging to wall paintings corresponding to some historical buildings of Sevillian art, Journal of Thermal Analysis and Calorimetry 92 (2008) 353-359.

[11] A. Bakolas, G. Biscontin, V. Contardi, E. Franceschi, A. Moropoulou, D. Palazzi, E. Zendri, Thermoanalytical research on traditional mortars in Venice, Thermochimica Acta 269 (1995) 817-828.

[12] A. Iordanidis, J. Garcia-Guinea, A. Strati, A. Gkimourtzine, A. Papoulidou, Thermal, mineralogical and spectroscopic study of plasters from three post-Byzantine churches from Kastoria (northern Greece), Journal of Thermal Analysis and Calorimetry 103 (2011) 577-586.

[13] W. Bartz, T. Filar, Mineralogical characterization of rendering mortars from decorative details of a baroque building in Kozuchow (SW Poland), Materials Characterization 61 (2010) 105-115.

[14] P. Cardiano, S. Sergi, C. De Stefano, S. Ioppolo, P. Piraino, Investigations on ancient mortars from the Basilian monastery of Fragala, Journal of Thermal Analysis and Calorimetry 91 (2008) 477-485.

[15] J.I. Alvarez, I. Navarro, P.J.G. Casado, Thermal, mineralogical and chemical studies of the mortars used in the cathedral of Pamplona (Spain), Thermochimica Acta 365 (2000) 177-187.

[16] A. Moropoulou, A. Bakolas, K. Bisbikou, Characterization of ancient, Byzantine and later historic mortars by thermal and X-ray diffraction techniques, Thermochimica Acta 269 (1995) 779-795.

[17] G.M. Ingo, I. Fragala, G. Bultrini, T. de Caro, C. Riccucci, G. Chiozzini, Thermal and microchemical investigation of Phoenician-Punic mortars used for lining cisterns at Tharros (western Sardinia, Italy), Thermochimica Acta 418 (2004) 53-60.

[18] J. Sanjurjo-Sanchez, M.J. Trindade, R. Blanco-Rotea, R. Benavides Garcia, D. Fernandez Mosquera, C. Burbidge, M.I. Prudencio, M.I. Dias, Chemical and mineralogical characterization of historic mortars from the Santa Eulalia de Boveda temple, NW Spain, Journal of Archaeological Science 37 (2010) 2346-2351.

[19] S. Vecchio, A. Laginestra, A. Frezza, C. Ferragina, The use of thermoanalytical techniques in the characterization of ancient mortars, Thermochimica Acta 227 (1993) 215-223.

[20] L. Paama, I. Pitkanen, H. Ronkkomaki, P. Peramaki, Thermal and infrared spectroscopic characterization of historical mortars, Thermochimica Acta 320 (1998) 127-133.

[21] J. Adams, W. Kneller, D. Dollimore, Thermal analysis (TA) of lime- and gypsum-based medieval mortars, Thermochimica Acta 211 (1992) 93-106.

[22] L.M. Belloni, Il castello Baradello. Zona A., Edizioni New Press, 1980.

[23] M. Biraghi, L. Castelletti, I. Nobile, C. Orsenigo, Le nuove scoperte archeologiche, in L. Marchiò, Baradello e dintorni. Storia e restauro del simbolo di Como, Edizioni New Press, Cermenate (CO), 2012, pp. 82-88.

[24] A. Bakolas, G. Biscontin, A. Moropoulou, E. Zendri, Characterization of structural byzantine mortars by thermogravimetric analysis, Thermochimica Acta 321 (1998) 151-160.

[25] A. Santos Silva, M. Paiva, J. Ricardo, M. Salta, A.M. Monteiro, A.E. Candeias, Characterisation of roman mortars from the archaeological site of Tróia (Portugal), Materials Science Forum 514-516 (2006) 1643-1647. 
[26] A.L. Velosa, J. Coroado, M.R. Veiga, F. Rocha, Characterisation of roman mortars from Conímbriga with respect to their repair, Materials Characterization 58 (2007) 1208-1216.

[27] Vitruvius, On Architecture, Harvard University Press, Cambridge, 1933.

[28] H.G.M. Edwards, D.W. Farwell, The conservational heritage of wall paintings and buildings: an FT-Raman spectroscopic study of prehistoric, Roman, mediaeval and Renaissance lime substrates and mortars, Journal of Raman Spectroscopy 39 (2008) 985-992.

[29] A. Moropoulou, A. Bakolas, K. Bisbikou, Investigation of the technology of historic mortars, Journal of Cultural Heritage 1 (2000) 45-58.

[30] C. Genestar, C. Pons, Ancient covering plaster mortars from several convents and Islamic and Gothic palaces in Palma de Mallorca (Spain). Analytical characterisation, Journal of Cultural Heritage 4 (2003) 291-298.

[31] N. Prieto-Taboada, M. Maguregui, I. Martinez-Arkarazo, M.A. Olazabal, G. Arana, J.M. Madariaga, Spectroscopic evaluation of the environmental impact on black crusted modern mortars in urban-industrial areas, Analytical and Bioanalytical Chemistry 399 (2011) 2949-2959.

[32] D. Chakrabarty, S. Mahapatra, Aragonite crystals with unconventional morphologies, Journal of Materials Chemistry 9 (1999) 2953-2957.

[33] M.R. Derrick, D. Stulik, J.M. Landry, Infrared Spectroscopy in Conservation Science, The Getty Conservation Institute, Los Angeles, 1999.

[34] S. Gunasekaran, G. Anbalagan, S. Pandi, Raman and infrared spectra of carbonates of calcite structure, Journal of Raman Spectroscopy 37 (2006) 892-899.

[35] V. Reyes-Zamudio, C. Angeles-Chávez, J. Cervantes, Clay minerals in historic buildings, Journal of Thermal Analysis and Calorimetry 104 (2011) 405-413.

[36] A. Duran, L.A. Perez-Maqueda, J. Poyato, J.L. Perez-Rodriguez, A thermal study approach to Roman age wall painting mortars, Journal of Thermal Analysis and Calorimetry 99 (2010) 803-809.

[37] M.V. Borrachero, J. Payá, M. Bonilla, J. Monzó, The use of thermogravimetric analysis technique for the characterization of construction materials, Journal of Thermal Analysis and Calorimetry 91 (2008) 503-509.

[38] A. Bakolas, G. Biscontin, A. Moropoulou, E. Zendri, Characterization of the lumps in the mortars of historic masonry, Thermochimica Acta 269 (1995) 809-816.

[39] R. Bugini, L. Folli, A. Lommano, Plaster technologies in Northern Italy from 15th to 19th century, 8th International Congress on deterioration and conservation of stone (Berlin, 30/9-4/10 1996). Proceedings (1996) pag. $1495-1503$. 